\title{
A Study on Socio-Economic Status and Personality of Pupil Teachers with Special Reference to Gender
}

\author{
Mr. Sanjeet Kumar Tiwari ${ }^{1}$, Mr. Jubraj Khamari ${ }^{2}$ \\ Dr. Parvinder Hanspal ${ }^{3}$, Mr. Mirza Mahmood Baig ${ }^{4}$ \\ 1,2,3,4(School of Education, MATS University, Raipur, C.G., INDIA)
}

\begin{abstract}
The present research work intent to study the socio-economic status and personality of pupil teacher (B.Ed.) trainee on the basis of gender. Hence the researchers aim at to find out the socio-economic status (SES) of pupil teachers according to gender and to study the personality of pupil teachers according to gender. Researchers selecting 1000 samples out of total population on the basis random sampling techniques with the help of standardized tools collected data and on the basis of normative survey method analysis and interpretation with required statistical technique like Mean, Standard Deviation, Critical Ratio, Degree of Freedom, Coefficient of Correlation, and ANOVA tested the hypotheses find out the purposive findings to focus on proper suggestive suggestion towards conclusion.
\end{abstract}

Keywords: Socio-economic Status, Personality, Pupil Teacher and Gender.

Back Ground of the Study: -

\section{Introduction}

"All men differ from each other since neither environment nor disposition can ever in any two men be the same or alike."

\section{By - Robert Bridges, Testament of Beauty}

Education is modification of behaviour of the individual in a socially desirable way coming through the contact of its environment for adequate adjustment in the society to personify the personality to influence person on the basis of his/her socio-economical status.

Socio-economic status (SES) is an economic and sociological combined total measure of a person's work, experience and of an individual or family's economical and social position relative to others. Socioeconomic status is typically broken into three categories high SES, average SES and low SES. To describe the three areas, a family or an individual may fall into one of these categories. Any or all of the three variables (income, education and occupation) can be assessed. A fourth variable wealth may also be examined when determining socio-economic status.

An individual's personality is his unique pattern of traits. No two individuals, even the identical twins have alike personality. Personality also is a product of its own functioning. What we do today depends on our accumulated experiences of the past. The experiences are accumulated day after day and shape our personality by continuous interaction with external environment. Personality is what makes individual unique. A future teacher should be responsible, emotionally stable, friendliness, curious, dominant and should have self concept in personality.

Here the researcher has keen interest to know how much and what level based on socio-economic status of the pupil teachers particularly upon personality of them influenced whereby the problem introduce as "A study on socio-economic status and personality of pupil teachers with special reference to gender"

\section{Rational of the study:-}

Teaching is an art and Teacher is an artist whereby teacher education is the ambitions of pupil teachers to reach their destination in teacher education institutions not only in Raipur district of Chhattisgarh state but also in all over the word collaboration. But all-round development of personality and socio-economic status of the pupil teacher adversely effects and affects to a great extent in reality. As a reason different research study, different class room activities, different commission and committee and different psychological organization has been working on different variable to different situation in different research field to understand the problem and gives the suggestion toward these variation and critical justification in the field of teacher education especially to pupil teachers. So as a rational thinker the researcher in this present research work has thought such important as rational of the study. 
Objectives of the study: -

\section{Objectives And Hypotheses}

(1) To find out the socio - economic status (SES) of pupil teachers according to gender.

(2) To study the personality of pupil teachers according to gender.

Hypothesis of the Study: -

$\mathbf{H}_{1}$ There will be no significant difference in socio-economic status of pupil teachers according to gender.

$\mathbf{H}_{2}$ There will be no significant difference in personality of pupil teacher according to gender.

$\mathbf{H}_{2.1}$ No significant difference will be observed in personality of male and female pupil teachers of low socioeconomic status.

$\mathbf{H}_{2.2}$ No significant difference will be observed in personality of male and female pupil teachers of middle socio-economic status.

$\mathbf{H}_{2.3}$ No significant difference will be observed in personality of male and female pupil teachers of high socioeconomic status.

Method: -

\section{Methodology And Procedure}

Based on the present study, survey method needs to prepare the layout of the method of the following steps in taking proper samples, collecting data, adopting suitable technique to arrive at desired results and verification of the hypotheses.

Population: -

The present research work entrusted all the pupil teachers enrolled during the session 2013-14 of all the teacher education institutions to constitute the population for smooth and successful completion of the study.

\section{Sample: -}

The researcher will select 1000 samples (500 male and 500 female) B.Ed. students out of total population through random sampling technique for systematic and competitive analysis as per the proportionate availability of population constituted within the concerned area of the study.

\section{Scope and Delimitation: -}

The present research work covers the complete teacher education territory of Chhattisgarh state as the scope of the study and all the B.Ed. students (pupil teachers) of B.Ed. departments of all the teachers education institutions of the state delimited to the study.

Tools: - The following tools are selected for the study.

1. Rajbir Singh, Radhey Shyam and Satish Kumar, socio - economic status scale (SESS-SSK) Hindi / English.

2. Arun Kumar Singh and Ashish Kumar Singh, Differential Personality Inventory (DPI-SS) Hindi / English.

\section{Statistical Techniques: -}

The researcher used Mean, Standard Deviation, Critical Ratio, Degree of Freedom, Coefficient of Correlation, and ANOVA the required statistical techniques as per the requirements for successful statistical analysis of data to achieve the stated objectives relating to supported hypotheses formulated expecting outcomes.

\section{Research Procedure:}

The main base of Educational Research, investigation or survey is real fact related with study. These facts are collected with the help of observation, interview, schedule and questionnaire. In the present work data has been collected from target colleges by administering two tests of home environment and values of pupil teachers. But of course, these collected data are always unsettled in their primary stage. Since the raw data as such is in the form of digits and figures, which are rather incomprehensible to laymen. Therefore, it is not possible to take out conclusions from them or to understand them in their original form as well unless they are analyzed systematically. Hence, suitable statistical procedures are adopted for tabulation and organization of the raw data.In this chapter the data thus collected are systematically classified, tabulated and represented in suitable graphical manner useful for their interpretation in the context of the present work. These data are then required to be analyzed and to reveal a clear picture to test the hypothesis and arrive at the conclusion. 
Another most important aspect of research is ANALYSIS. It is the process where relationship or difference supporting or opposing to the original or new hypothesis should be subjected to statistical test of significance to determine with what validity data can be said to indicate conclusions

\section{Tabulation of Data:}

In this research work the researcher has taken 1000 sample. Out of which 500 are male pupil teacher and 500 are female pupil teachers. After administering the test for ascertaining socio-economic status, the total sample is distributed in three major categories i.e. of low socio-economic status, medium socio-economic status and high socio-economic status. The distribution of sample in numeral form is presented in this table:-

Tabulation of Data Collected:

\begin{tabular}{|l|l|l|l|}
\hline SES & MALE & FEMALE & TOTAL \\
\hline LOW & 120 & 101 & 221 \\
\hline MIDDLE & 272 & 255 & 527 \\
\hline HIGH & 108 & 144 & 252 \\
\hline TOTAL & $\mathbf{5 0 0}$ & $\mathbf{5 0 0}$ & $\mathbf{1 0 0 0}$ \\
\hline
\end{tabular}

IV. Analysis And Interpretation Of Data

As we know that the qualitative data cannot be shown in numerical from. Therefore analysis of these types of data is very essential. Analysis of Data means studying the tabulated material in order to determine inherent facts or meanings on the basis of statistics applied.

Interpretation is certainly a mechanical process. It requires a critical examination of the results of analysis done in the light of all the limitations of data gathered. It is a very important step in the total procedure of research.Graphic representation at a glance gives a general notion of the whole data and is easier to read and figure out than a table

\section{Personality}

The Personality scale has been divided in ten dimensions which are as follows:-

\begin{tabular}{|l|l|l|}
\hline S. No. & Area & Dimensions \\
\hline 1. & Area 1 & Decisiveness \\
\hline 2. & Area 2 & Responsibility \\
\hline 3. & Area 3 & Emotional Stability \\
\hline 4. & Area 4 & Masculinity \\
\hline 5. & Area 5 & Friendliness \\
\hline 6. & Area 6 & Heterosexuality \\
\hline 7. & Area 7 & Ego-Strength \\
\hline 8. & Area 8 & Curiosity \\
\hline 9. & Area 9 & Dominance \\
\hline 10. & Area 10 & Self-concept \\
\hline
\end{tabular}

With the help of above procedure the researcher used Mean, Standard Deviation, Critical Ratio, Degree of Freedom and Coefficient of Correlation the required statistical techniques as per the requirements for successful statistical analysis of data to achieve the stated objectives relating to supported hypotheses formulated expecting outcomes.

\section{Verification of Hypotheses:}

Differential Hypothesis:

$\mathbf{H}_{1}$ There will be no significant difference in socio-economic status of pupil teachers according to gender.

Table.5.2

Significance of Mean Difference of Socio-Economic Status of Male and Female Pupil Teachers

\begin{tabular}{|l|l|c|c|c|c|c|c|c|}
\hline $\begin{array}{l}\text { S. } \\
\text { No }\end{array}$ & Group & $\begin{array}{c}\text { No. of Pupil } \\
\text { Teachers } \\
\text { (N) }\end{array}$ & $\begin{array}{c}\text { Mean } \\
(\mathbf{M})\end{array}$ & $\begin{array}{c}\text { Standard } \\
\text { Deviation } \\
\text { (S.D.) }\end{array}$ & $\begin{array}{c}\text { Critical } \\
\text { Ratio } \\
\text { (C.R.) }\end{array}$ & $\begin{array}{c}\text { Degree of } \\
\text { freedom } \\
(\boldsymbol{d} f)\end{array}$ & $\begin{array}{c}\text { At 0.01 } \\
\text { Significance } \\
\text { level }\end{array}$ & $\begin{array}{c}\text { At 0.05 } \\
\text { Significan } \\
\text { ce level }\end{array}$ \\
\hline 1 & Male & 500 & 81.42 & 33.79 & 3.92 & 998 & 2.59 & 1.96 \\
\hline 2 & Female & 500 & 90.54 & 39.53 & 3.53 & & & \\
\hline & Total & 1000 & & & & & & \\
\hline
\end{tabular}

\section{Explanation}

At 998 degree of freedom $(d f)$, table value of C.R. at 0.01 significance level is 2.59 and at 0.05 level is 1.96. Value of C.R. calculated is 3.92, which is greater than table value of C.R. at both 0.01 and 0.05 level of significance i.e. 2.59 and 1.96. Therefore the Null Hypothesis is rejected here and it is found that there is significant mean difference in socio-economic status of pupil teachers according to gender. Hence, the 
hypothesis of the study is not approved here and there exists difference in the socio-economic status of male and female pupil teacher

\section{Graph 1 Graph Showing Mean and Standard Deviation of Socio-Economic Status of Male and Female} Pupil Teachers

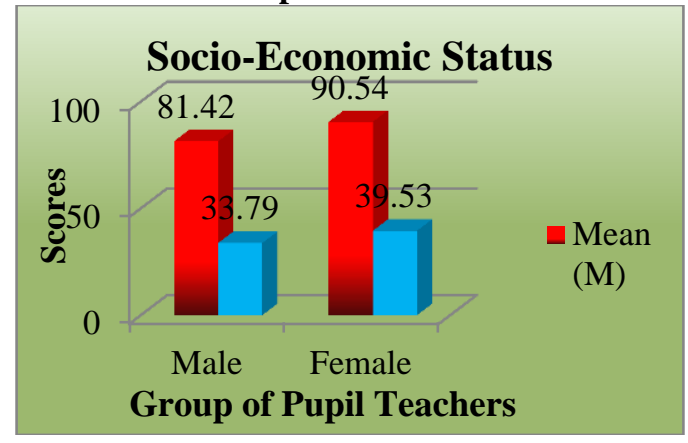

$\mathbf{H}_{2}$ There will be no significant difference in personality of pupil teacher according to gender.

$\mathbf{H}_{2.1}$ No significant difference will be observed in personality of male and female pupil teachers of low socio-economic status.

Table.5.3 Significance of Mean Difference of Personality of Male and Female Pupil Teachers of Low Socio-Economic Status

\begin{tabular}{|c|c|c|c|c|c|c|c|c|}
\hline $\begin{array}{l}\text { S. } \\
\text { No }\end{array}$ & Group & $\begin{array}{l}\text { No. of Pupil } \\
\text { Teachers (N) }\end{array}$ & $\begin{array}{c}\text { Mean } \\
(\mathrm{M})\end{array}$ & $\begin{array}{c}\text { Standard } \\
\text { Deviation } \\
\text { (S.D.) }\end{array}$ & $\begin{array}{c}\text { Critical } \\
\text { Ratio (C.R.) }\end{array}$ & $\begin{array}{c}\text { Degree of } \\
\text { freedom }(d f)\end{array}$ & $\begin{array}{c}\text { At } 0.01 \\
\text { Significance } \\
\text { level }\end{array}$ & $\begin{array}{c}\text { At } 0.05 \\
\text { Significan } \\
\text { ce level }\end{array}$ \\
\hline 1 & Male & 120 & 81.68 & 9.32 & \multirow{2}{*}{1.78} & \multirow{2}{*}{219} & \multirow{2}{*}{2.59} & \multirow{2}{*}{1.97} \\
\hline 2 & Female & 101 & 79.5 & 8.85 & & & & \\
\hline & Total & 221 & & & & & & \\
\hline
\end{tabular}

\section{Explanation}

Table no.4.3 shows that at 219 degree of freedom $(d f)$, table value of C.R. at 0.01 significance level is 2.59 and at 0.05 level is 1.97. Value of C.R. calculated is 1.78 , which is less than both the table values of C.R. at 0.01 and 0.05 level of significance i.e.- 2.59 and 1.97. Therefore the Null Hypothesis is accepted here and it is observed that there is no significant mean difference in personality of male and female pupil teachers of low socio-economic status. Hence, the hypothesis of the study is approved.

\section{Graph 2}

Graph Showing Mean and Standard Deviation of Personality of Male and Female Pupil Teachers of Low Socio-Economic Status

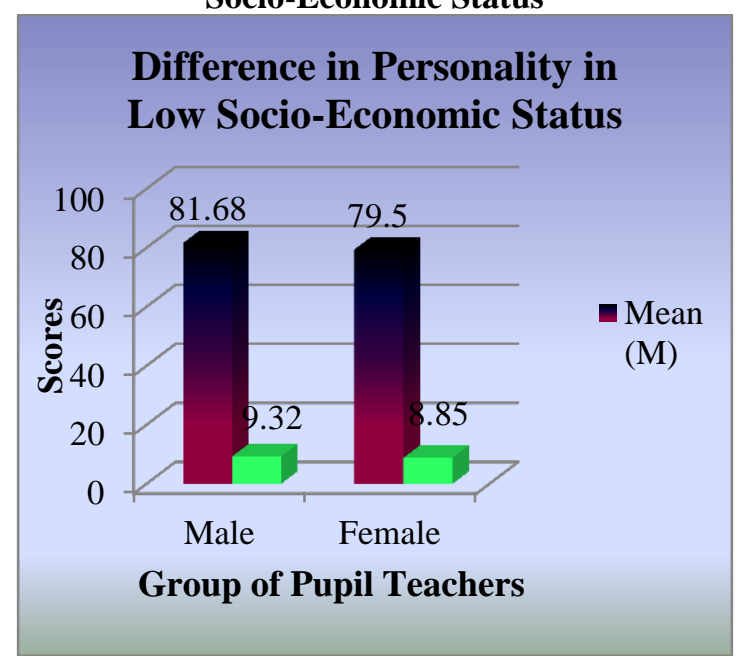

$\mathbf{H}_{\text {2.2 }}$ No significant difference will be observed in personality of male and female pupil teachers of middle socio-economic status. 
Table.5.4

Significance of Mean Difference of Personality of Male and Female Pupil Teachers of Middle SocioEconomic Status

\begin{tabular}{|c|l|c|c|c|c|c|c|c|}
\hline $\begin{array}{l}\text { S. } \\
\text { No }\end{array}$ & Group & $\begin{array}{c}\text { No. of Pupil } \\
\text { Teachers (N) }\end{array}$ & $\begin{array}{c}\text { Mean } \\
\text { (M) }\end{array}$ & $\begin{array}{c}\text { Standard } \\
\text { Deviation } \\
\text { (S.D.) }\end{array}$ & $\begin{array}{c}\text { Critical } \\
\text { Ratio } \\
\text { (C.R.) }\end{array}$ & $\begin{array}{c}\text { Degree of } \\
\text { freedom } \\
(\boldsymbol{d} f)\end{array}$ & $\begin{array}{c}\text { At 0.01 } \\
\text { Significance } \\
\text { level }\end{array}$ & $\begin{array}{c}\text { At 0.05 } \\
\text { Significa } \\
\text { nce level }\end{array}$ \\
\hline 1 & Male & 272 & 81.28 & 9.34 & 0.96 & 525 & 2.58 \\
\hline 2 & Female & 255 & 80.51 & 9.08 & & & \multirow{2}{*}{1.96} \\
\hline & Total & 527 & & & & & & \\
\hline
\end{tabular}

\section{Explanation}

Table no.4.4 shows that at 525 degree of freedom $(d f)$, table value of C.R. at 0.01 significance level is 2.58 and at 0.05 level is 1.96. Value of C.R. calculated is 0.96 , which is less than both the table values of C.R. at 0.01 and 0.05 level of significance i.e.- 2.58 and 1.96. Therefore the Null Hypothesis is accepted here and it is observed that there is no significant mean difference in personality of male and female pupil teachers of middle socio-economic status. Hence, the hypothesis framed in the study is approved.

Graph 3

Graph Showing Mean and Standard Deviation of Personality of Male and Female Pupil Teachers of Middle Socio-Economic Status

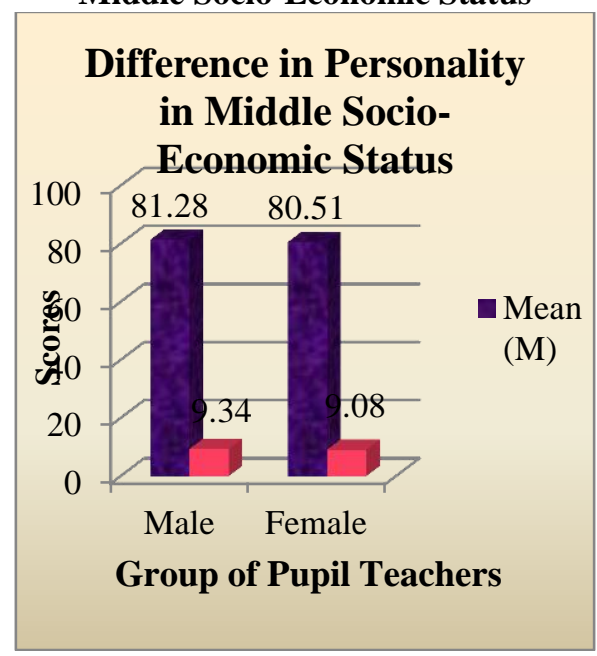

$\mathbf{H}_{2.3}$ No significant difference will be observed in personality of male and female pupil teachers of high socio-economic status.

Table.5.5

Significance of Mean Difference of Personality of Male and Female Pupil Teachers of High SocioEconomic Status

\begin{tabular}{|c|c|c|c|c|c|c|c|c|}
\hline $\begin{array}{l}\text { S. } \\
\text { No }\end{array}$ & Group & $\begin{array}{l}\text { No. of Pupil } \\
\text { Teachers (N) }\end{array}$ & $\begin{array}{c}\text { Mean } \\
(\mathrm{M})\end{array}$ & $\begin{array}{c}\text { Standard } \\
\text { Deviation } \\
\text { (S.D.) } \\
\end{array}$ & $\begin{array}{c}\text { Critical } \\
\text { Ratio } \\
\text { (C.R.) }\end{array}$ & $\begin{array}{c}\text { Degree of } \\
\text { freedom }(d f)\end{array}$ & $\begin{array}{c}\text { At } 0.01 \\
\text { Significance } \\
\text { level }\end{array}$ & $\begin{array}{c}\text { At } 0.05 \\
\text { Significan } \\
\text { ce level } \\
\end{array}$ \\
\hline 1 & Male & 108 & 79.61 & 8.84 & \multirow{2}{*}{1.39} & \multirow{2}{*}{250} & \multirow{2}{*}{2.59} & \multirow{2}{*}{1.97} \\
\hline 2 & Female & 144 & 81.2 & 9.2 & & & & \\
\hline & Total & 252 & & & & & & \\
\hline
\end{tabular}

\section{Explanation}

Table no.4.5 shows that at 250 degree of freedom $(d f)$, table value of C.R. at 0.01 significance level is 2.59 and at 0.05 level is 1.97. Value of C.R. calculated is 1.39 , which is less than both the table values of C.R. at 0.01 and 0.05 level of significance i.e.- 2.59 and 1.97. Therefore the Null Hypothesis is accepted here and it is observed that there is no significant mean difference in personality of male and female pupil teachers of high socio-economic status. Hence, the hypothesis framed in the study is approved. 
Graph 4Graph Showing Mean and Standard Deviation of Personality of Male and Female Pupil Teachers of High Socio-Economic Status

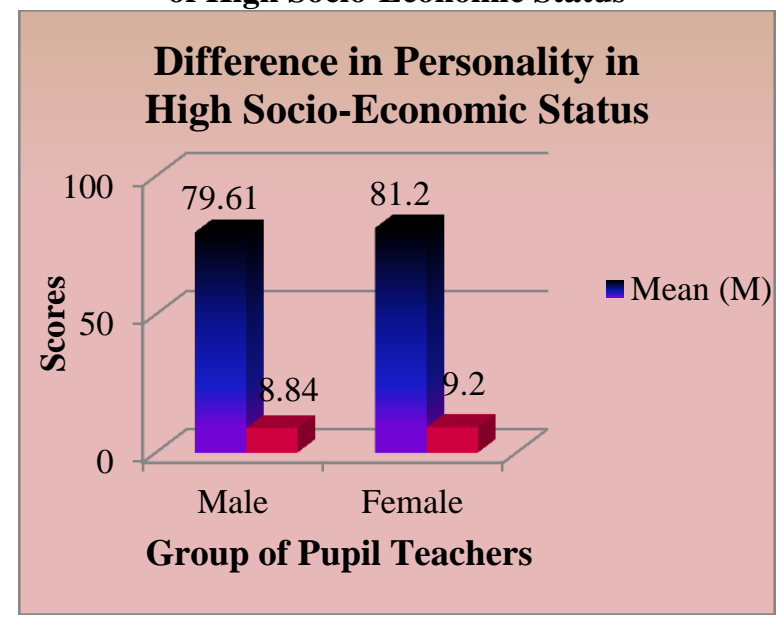

\section{Findings And Suggestions Of The Study}

$\mathbf{H}_{\mathbf{1}} \quad$ There will be no significant difference in socio-economic status of pupil teachers according to gender. Finding: It is found that there is significant mean difference in socio-economic status of pupil teachers according to gender. Hence, the hypothesis of the study is not approved here and there exists difference in the socio-economic status of male and female pupil teachers.

Suggestion: It can be suggested that to reduce the significance mean difference in socio economic status of the pupil teachers according to gender is a great Challenge.

$\mathbf{H}_{2} \quad$ There will be no significant difference in personality of pupil teacher according to gender.

$\mathbf{H}_{2.1}$ No significant difference will be observed in personality of male and female pupil teachers of low socio-economic status.

Finding: It is found that there is no significant mean difference in personality of male and female pupil teachers of low socio-economic status. Hence, the hypothesis of the study is approved.

$\mathbf{H}_{2.2}$ No significant difference will be observed in personality of male and female pupil teachers of middle socio-economic status.

Finding: It is observed that there is no significant mean difference in personality of male and female pupil teachers of middle socio-economic status. Hence, the hypothesis framed in the study is approved.

$\mathbf{H}_{2.3}$ No significant difference will be observed in personality of male and female pupil teachers of high socio-economic status.

Finding: It is observed that there is no significant mean difference in personality of male and female pupil teachers of high socio-economic status. Hence, the hypothesis framed in the study is approved.

Suggestion: It can be suggested that there will be no requirement of any statistical manipulation so far as the stated and tested hypotheses headed by second hypothesis is concerned.

\section{Conclusion of the Study:}

On the basis of above findings and suggestions researcher concluded that There will be significant difference in socio-economic status of pupil teachers according to gender and other all the hypotheses are Viceverses as a result there is not significance difference on ten dimension of personality of pupil teachers with reference to Socio-economical status.

\section{References:}

[1]. Ameerjan, M.S and M.S. Thimappa (1993). Extroversion and Neuroticism as related to socioeconomic level and caste affiliation. Journal of Psychological Researches, 37 (3), 26-29.

[2]. Anastasi, A., (1988). Psychological Testing, 6th Edition, Macmillan, New York.

[3]. Allen, Bem P. (1994), Personality Theories ( pp.5,6,11-14),

[4]. Allport, G.W. (1937). Personality: A Psychological Interpretation. New York: Holt, Rinehart and Winston.

[5]. Best J.W and Khan J (1992). Research in Education (6 ${ }^{\text {th }}$ edition) New Delhi Prentice Hall of India Pvt. Ltd.

[6]. Boggiano, A.K. Main D.S and Katz P.A. (1990). Children's Preference for Challenge. The role of perceived competence and control. Journal of Personality and Social Psychology, 54, 134-141.

[7]. Buch, M.B., (1983). Fourth Survey of Educational Research, New Delhi. N.C.E.R.T. 
[8]. Burns, R.B. (1980). The Self-concept Theory, Measurement Development and Behavior, McGraw-Hill.

[9]. Buch, M.B., (1987). Third Survey of Educational Research, New Delhi N.C.E.R.T.

[10]. Cattel, R.B. (1943). The description of personality: Basic traits resolved into clusters. Journal of Abnormal and Social Psychology, $38,476-506$.

[11]. Cattell, R. B. (1950). Personality: A systematic, theoretical, and factual study. New York: McGraw-Hill

[12]. Cattell, R. B. (1965). The scientific analysis of personality. Baltimore: Penguin Books

[13]. Department of Psychology, University of British Columbia (2007). Impact of Socioeconomic Status on Physiological Health in Adolescents: an Experimental Manipulation of Psychosocial Factors, Vancouver, British Columbia, Canada.

[14]. Duncan, G.J.: Day, M.C.; McDonough, P. and Williams, D. R. (2002). Optimal indicators of socio-economic status for health research. American Journal of Public Health, 92, 1151-1157.

[15]. Dweck, C.S and Leggett, E.L (1988). A social-cognitive approach to motivation and personality, Psychological Review, 95, $256-$ 273.

[16]. Digman, J. M. (1990). Personality structure: Emergence of the five-factor model. Annual Review of Psychology, 41, 417-440.

[17]. Edwards, A.L. (1957). The Social desirability variable in Personality assessment and research, New York : Dryden Press.

[18]. Eysenck, H.J. (1947). Dimensions of Personality, London : Routledge and Regan Paul.

[19]. Eysenck, H. (1967). The biological basis of personality. Springfield, 11,: Charles C.Thomas

[20]. Eysenck, H. and Eysenck, M. (1985). Personality and individual differences: a natural science approach. New York: Plenum.

[21]. Eysenck, H. J. (1991). Personality, stress, and disease: An interactionist perspective. Psychological Inquiry, 2, 221-232.

[22]. Guilford, J.P. (1954). Psychometric Methods, (2 $2^{\text {nd }}$ ed.), New York : McGraw-Hill.

[23]. Guilford, J.P. (1956). Fundamental statistics in Psychology and Education, McGraw-Hill Book Company, INC

[24]. Garrett H E: (1981). Statistics in Psychology and Education, Indian Edition, Bombay Vakils,Feffer \& Simons Ltd.

[25]. Goldberg, L. R. (1990). An alternative "description of personality": The Big-Five factor structure. Journal of Personality and Social Psychology, 59, 1216-1229.

[26]. Holland J. L: (1960) "The Prediction of College Grades from Personality \& Aptitude Variables", J Education Psychology, 51.

[27]. Jain Smita (1992). A Study of creativity in relation to the teaching aptitude, skills and personality variables of pupil teachers, Nagpur University, India.

[28]. Kuppuswamy, B. (1960). An analysis of some variable involved in socio-economic variable. Journal of Education and Psychology, 18.

[29]. Lawrence, A.P. (1986). Personality, New York: John Wiley and Sons INC.

[30]. Mangal, S.K., (1993). Advanced Educational Psychology, Prentice Hall, New Delhi, India.

[31]. Piko, B. and Fitzpatrick, K. M. (2001). Does class matter? SES and Psychological health among Hungarian adolescents. Social Science Medicine, 53, 817-830.

[32]. Powers, M.G. (1981). Measures of socio-economic status : An Introduction, In M.G.

[33]. S. Suresh, S. Kadhiravam. (1992).Influence of personality on the environmental awareness ability of college students. Journal of Community Guidance and Research 2007 Vol. 24 No. PP. 58-59.

[34]. Shukla, S.K. and Agrawal Archana (1997). A study of socio - economic status, intelligence, occupational aspiration, self concept and Academic achievement of scheduled caste and non-scheduled caste students, Indian Journal of Education Research 1, 15-19.

[35]. Sirin, S. R. (2005). Socioeconomic status and academic achievement: A meta-analytic review of research. Review of Educational Research, 75, 417-453. 